\title{
PHYSICOCHEMICAL PROPERTIES OF WATER COURSES IN TATRA NATIONAL PARK
}

The aim of this study is to present an informative overview of the physicochemical properties of a representative sample of water courses located within Tatra National Park. The water quality of 28 selected water courses was monitored at altitudes from 639 to $2002 \mathrm{~m}$ a.s.l. Water temperature, $p H$, conductivity, concentrations of total dissolved solids, salinity and dissolved oxygen were measured from June to October 2010. The concentration of dissolved oxygen ranged from 5.90 to $16.46 \mathrm{mg} / \mathrm{l}$, conductivity ranged from 5.30 to $282.60 \mu \mathrm{S} / \mathrm{cm}$ and $\mathrm{pH}$ averaged 7.25 . An inverse relationship was found between nitrate and altitude as well as between conductivity and altitude. Measurements were consistent with the rating for very pure water. The results obtained serve as initial findings and form the basis for further biotic monitoring of water quality in the Tatra Mountains.

Keywords: Physicochemical, Tatra Mountains, water courses, water quality.

\section{Introduction}

The habitats of Tatra National Park (TANAP) have undergone significant environmental impacts, especially in the last decade. A storm in 2004 caused substantial damage to forest stands. Changes in vegetation cover, including deforestation, usually result in disruption of biochemical cycles, hydrology and ecology in terrestrial and aquatic environments [1].

Surface water courses are a very important component of mountain environments. Their properties reflect both natural and anthropogenic processes [1,2]. Climate, geology, topography as well as soil and vegetation cover are some of the main factors affecting water quality $[3,4]$. Contrary to lowlands, where the vertical flow of nutrients in the soil-plant-atmosphere system predominates, the system in mountains depends more on various phenomena mutually interconnected to altitude [5].

Changes in the retention potential of subalpine areas have an indirect impact on other physicochemical parameters of mountain streams. In recent years there has been a significant loss of water run-off volume at some locations, especially in summer months. This situation has a direct impact on the climate of the locations. Globally, we can expect a trend towards a gradual increase in ambient temperatures in mountainous areas. High mountain ecosystems represent unique areas for the detection of climate change and the assessment of climate-related impacts [6]. Climate change associated with global warming is more pronounced at higher elevations [7]. The main ecological driving force is climate, with temperature and duration of snow cover as key factors [8]. Changes in air temperature can extend the length of the average annual growing season [9] and can also cause a shift in phenology [10].

The characteristic features of well-functioning landscapes are effectively operating nutrient cycles, balanced drainage conditions and minimal losses of nutrients by transport. The basic parameters for evaluating function and surface temperature oscillations are the quality of surface water run-off and its dynamics. These parameters can be considered as integral values where the values of spatial distribution and temporal variability are reflected in the key functional processes occurring in the biocenosis and their interaction with the environment [11]. Physicochemical parameters of water quality status reflect natural and anthropogenic changes in conditional land use [1].

The chemistry of surface water is very variable. Rainfall and snow have a considerable impact on stream water chemistry. Streams formed mainly by rainwater have a low content of soluble substances [12]. Human activities (combustion, traffic, emissions from agricultural and industrial plants) have a marked influence on atmospheric pollution and cause different types of environmental stress. They have a negative influence on human health as well as forest, soil, surface and groundwater quality.

The aim of this study was to obtain an informative overview of physicochemical properties of individual water courses located within TANAP in order to define their water quality. Spatial monitoring enabled us to compare water quality between streams independent of inter-annual fluctuations. The data obtained will serve as the basis for further studies. Subsequent, continuous monitoring of water courses within TANAP will provide a view of the dynamics

\footnotetext{
* Ondrej Gura, Jan Graban, Natalia Maximova, Eva Greguskova

Institute of High Mountain Biology, Tatranska Javorina, University of Zilina, E-mail: graban@uniza.sk
} 


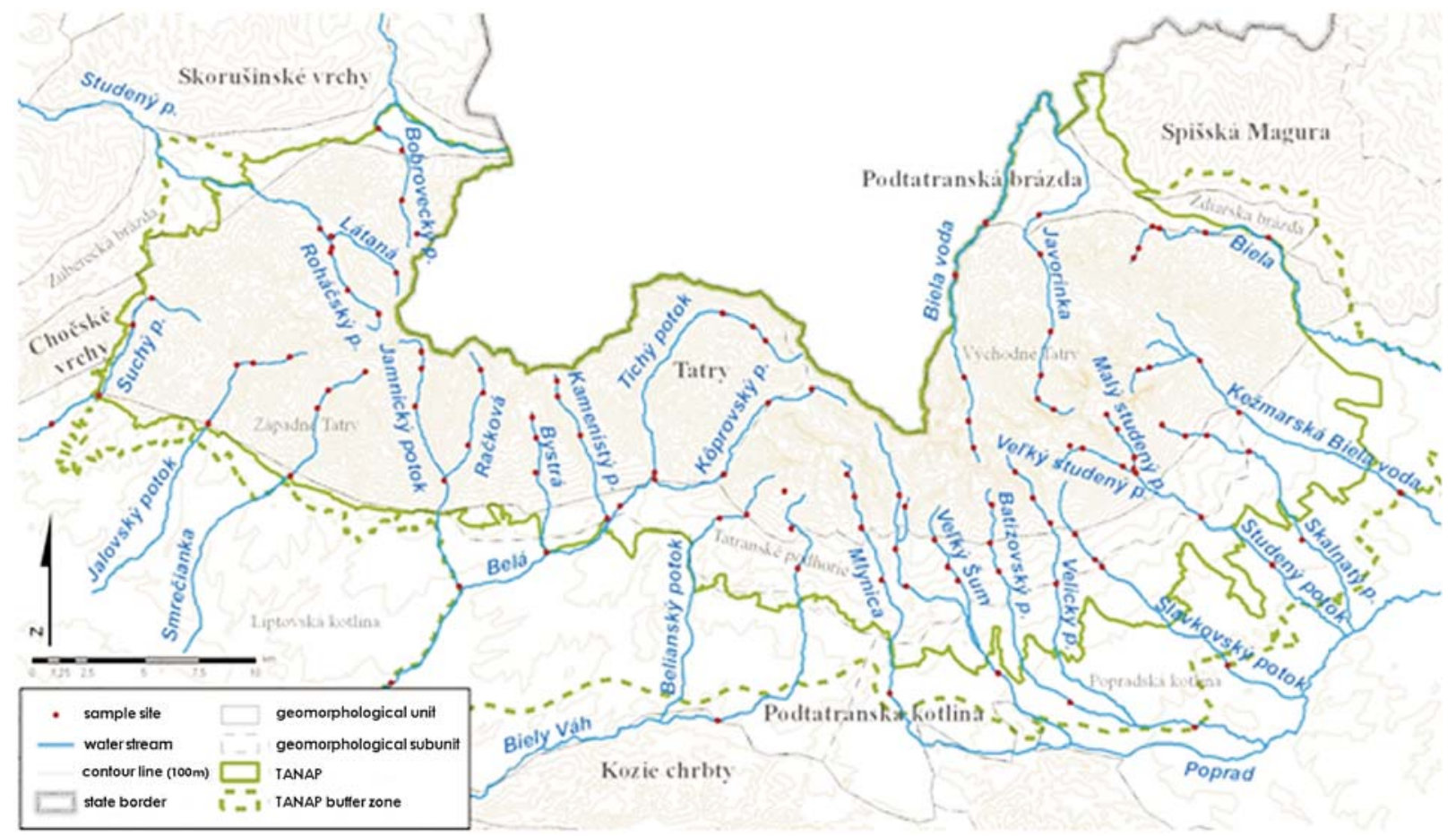

Fig. 1 Selected water courses in the Tatra National Park

of changes in the selected parameters according to anthropogenic impacts and climate change.

\section{Material and methods}

Study area

The Tatras are the highest mountains in the Western Carpathians and lie on the border between Slovakia and Poland. The southern part reaches into the Sub-Tatra Basin and northern part into the Sub-Tatra Trough. The High Tatra Mts. represent a typical fold mountain range composed of igneous rock [13]. The geology of the study area is based on crystalline bedrock. The Tatra Mts. contain significant biotite tonalities and granodiorites, locally porphyritic and also porphyritic granodiorites and granites [14]. The Western Tatra Mts. contain a significant amount of metamorphic rock (gneiss and mica schist) in addition to granodiorite [15]. The massif of the Tatra Mts. forms a European watershed [16]. The River Vah, rising in the Tatra Mts., flows to the Black Sea via the Danube, while the Poprad and Dunajec Rivers flow towards the Baltic Sea. Vegetation in the alpine zone of the Tatras is dominated by meadows with patches of dwarf pine (Pinus mugo) and, above the upper tree line at $1800 \mathrm{~m}$ a.s.l., a higher percentage of bare or lichen-covered rocks [17]. The area generally falls into the cold mountain zone with average temperatures $<10{ }^{\circ} \mathrm{C}$ in June. The lower parts and submontane areas belong to the lower mountain zone, with average temperatures of $12-16{ }^{\circ} \mathrm{C}$. Annual precipitation ranges from $600 \mathrm{~mm}$ in foothills to over $2000 \mathrm{~mm}$ at the highest altitudes [18].

\section{Sampling}

The research was carried out during the vegetation period, from June to October 2010. During this period, 28 water courses were monitored in TANAP. Samples were taken from four sites along an altitudinal gradient from montane up to the alpine region, $639-2002 \mathrm{~m}$ a.s.l. The following water courses were monitored in the east of the High Tatras: Biela voda (BIVO1-6), Javorinka (JAV1-6), Biela (BIE1-5), Kezmarska Biela voda (KBV1-5), Skalnaty potok (SKA1-5), Maly Studeny potok (MSTU1-4) and Velky Studeny potok (VSTU1-3) - which converge to form Studeny potok (STU4-6), Slavkovsky potok (SLA1-4), Velicky potok (VEL1-5), Batizovsky potok (BAT1-4), Velky Sum (VSUM1-3), Poprad (POP1-5), Mlynica (MLY1-5), Biely Vah (BVA1-4) and Beliansky potok (BEL1,2). In the west, the following water courses were selected: Tichy potok (TICH1-4) and Koprovsky potok (KOP1-4) - which converge to form the Bela (BELA1, 2), Kamenisty potok (KAM1-4), Bystra (BYS1-4), Rackov potok (RAC1-5), Jamnicky potok (JAM1-3), Smrecianka (SMR1-4), Jalovecky potok (JAL1-4), Suchy potok (SUCH1-4), Latana (LAT1-3), Rohacsky potok (ROH1-4) Studeny potok (STU) and Bobrovecky potok (BOB14) (Fig. 1). The selected water courses are described in $[19,13]$ and [20]. Each sampling site was fixed by GPS (WGS84 system, Decimal Degree Format).

At each sampling site, physical parameters such as $\mathrm{pH}$ (YSI pH100, YSI Inc., Ohio, USA), water temperature, conductivity (COND), concentrations of total dissolved solids (TDS), salinity (YSI EC300, YSI Inc., Ohio, USA) and dissolved oxygen (DO) (YSI DO200, YSI Inc., Ohio, USA) were measured in "in situ" 
conditions. Current weather, bank characteristics and potential sources of pollution were also recorded.

The following sources of pollution was detected in the selected areas of water courses:

Biela voda (BIVO1-6) - tourism, cottage

Javorinka (JAV1-6) - tourism, village Tatranska Javorina, logging

Biela (BIE1-5) - logging, Strednica ski resort, hotel Magura, cottages, village Zdiar

Kezmarska Biela voda (KBV1-5) - cottage at Zelene pleso, tourism, logging

Skalnaty potok (SKA1-5) - Encian hotel, ski resort TMR, logging, build-up area

Studeny potok (STU4-6) - Tery cottage, Zbojnicka cottage, tourism,

Slavkovsky potok (SLA1-4) - tourism, logging, build-up area

Velicky potok (VEL1-5) - Sliezky dom hotel, tourism, build-up area Batizovsky potok (BAT1-4) - cottage, logging, buid-up area

Velky Sum (VSUM1-3) - logging, build-up area

Poprad (POP1-5) - Popradske pleso hotel, tourism, agriculture, build-up area

Mlynica (MLY1-5) - tourism, Strbske pleso, agriculture, build-up area

Biely Vah (BVA1-4) - tourism, agriculture, build-up area

Beliansky potok (BEL1,2) - tourism, Tri studnicky cottage, logging

Tichy potok (TICH1-4) - tourism, Podbanske village

Koprovsky potok (KOP1-4) - tourism

Bela (BELA1, 2) - build-up area, agriculture

Kamenisty potok (KAM1-4) - tourism, cottages

Bystra (BYS1-4) - tourism, cottages

Rackov potok (RAC1-5) - tourism, build-up area

Jamnicky potok (JAM1-3) - tourism

Smrecianka (SMR1-4) - Ziarska cottage, tourism, build-up area, logging

Jalovecky potok (JAL1-4) - tourism, build-up area

Suchy potok (SUCH1-4) - cottage, Liptovske Matiasavce village

Latana (LAT1-3) - tourism, cottages

Rohacsky potok (ROH1-4) - Tatliakova cottage, Spalena ski resort

Bobrovecky potok (BOB1-4) - tourism, cottage, logging

Air temperature was measured at approximately $1 \mathrm{~m}$ above ground.

Similar chemical parameters were determined. Water was collected from the middle of the stream depth using sterile polyethylene bottles $(500 \mathrm{ml})$. Conservation and transportation of samples were performed according to [21].

\section{Laboratory analyses}

Concentrations of ammonium ions $\left(\mathrm{NH}_{4}^{+}\right)$, nitrate $\left(\mathrm{NO}_{3}{ }^{-}\right)$ and chloride ions $\left(\mathrm{Cl}^{-}\right)$were determined colorimetrically (YSI 9500 Photometer, YSI Inc., Ohio, USA). Total hardness (chelatometric titration) and chemical oxygen demand (COD) (manganometric titration) [22] were determined in the laboratory by titration. All chemical parameters were determined within 24 hours. All statistical analyses were performed with Statistica 8 software.

\section{Results}

Dissolved oxygen was found to range from $5.90 \mathrm{mg} / \mathrm{l}$ to 16.46 $\mathrm{mg} / \mathrm{l}$ and oxygen saturation from 45.70 to $122.63 \%$. The lowest value of DO was measured in Batizovsky stream (sampling site BAT1) and the highest in Biela (sampling site BIE6). DO decreased with increasing elevation. Concentrations began to decline as the water temperature rose (Fig. 2).

$\mathrm{pH}$ values were between 6.16 and 8.54. Most water courses had a close to neutral $\mathrm{pH}$. Only two streams, Biela and Suchy potok, had an alkaline character $(>8)$. $\mathrm{pH}$ was inversely proportional to elevation (Fig. 3).

Conductivity ranged from 5.30 to $282.60 \mu \mathrm{S} / \mathrm{cm}$, with an average of $36.3 \mu \mathrm{S} / \mathrm{cm}$. However, in most water courses CON was $<96 \mu \mathrm{S} / \mathrm{cm}$. A CON value greater than $100 \mu \mathrm{S} / \mathrm{cm}$ was found in two streams: Biela $(100.80-149.80 \mu \mathrm{S} / \mathrm{cm})$ and Suchy potok $(195.50-282.60 \mu \mathrm{S} / \mathrm{cm})$. An inverse relationship between altitude and conductivity was apparent (Fig. 4).

The water courses under study were generally very soft (e.g. Skalnaty potok, Studeny potok, Biely Vah, Smrecianka, Kamenisty potok etc.) or soft with a transition to medium hard water at a lower altitude with active anthropogenic activities (Biela, Bobrovecky potok, Javorinka). Suchy potok in the Western Tatras had moderately hard water.

COD concentration in most water courses did not exceed the limit of $3.00 \mathrm{mg} / 1$. Water samples from streams flowing through areas with anthropogenic activity had COD concentrations above $3.00 \mathrm{mg} / \mathrm{l}$ : Skalnaty potok $3.71 \mathrm{mg} / 1$ (736 m a.s.1.), Slavkovsky potok $3.81 \mathrm{mg} / 1(676 \mathrm{~m})$, Velicky potok $4.51 \mathrm{mg} / 1(689 \mathrm{~m})$, Batizovsky potok $3.95 \mathrm{mg} / 1(749 \mathrm{~m})$, Mlynica $3.60 \mathrm{mg} / 1(859 \mathrm{~m})$.

The limit value for ammonium ions $\left(\mathrm{NH}_{4}^{+}\right)$in surface water is set at $1.00 \mathrm{mg} / 1$. Our measurements of $\mathrm{NH}_{4}^{+}$did not exceed this limit, with observed values ranging between 0.00 and $0.37 \mathrm{mg} / 1$. The concentration of NH4+ did not exceed the value of $0.10 \mathrm{mg} / \mathrm{l}$ in most water courses, although higher concentrations were observed in three streams: Skalnaty potok (SKA2) $0.21 \mathrm{mg} / 1$, Batizovsky potok (BAT4) $0.23 \mathrm{mg} / \mathrm{l}$ and Velicky potok (VEL1) $0.37 \mathrm{mg} / \mathrm{l}$. No relationship between ammonium and altitude was observed (Fig. 5).

Measurements of nitrate anions ranged from 0.42 to $4.34 \mathrm{mg} / 1$. The highest value was observed in Mlynica stream ( $859 \mathrm{~m}$ a.s.1.) and the lowest value in Kamenisty potok $(1633 \mathrm{~m})$. The mean concentration was $1.17 \mathrm{mg} / \mathrm{l}$. A positive correlation was found between TDS and concentration of nitrate ions. There was an inverse relationship between nitrate and elevation (Fig. 5).

Measurements of chlorides ranged from 0.00 to $4.70 \mathrm{mg} / 1$, with a mean of $0.50 \mathrm{mg} / 1$. The highest value was found in Mlynica. Zero values of $\mathrm{C}^{-}$anions were observed in the following water courses: Bielka (953 m a.s.1.), Velky Sum (1109 m), Poprad (1267 m), Mlynica (1488 m), Kamenisty potok (1633 m), Rackov potok 


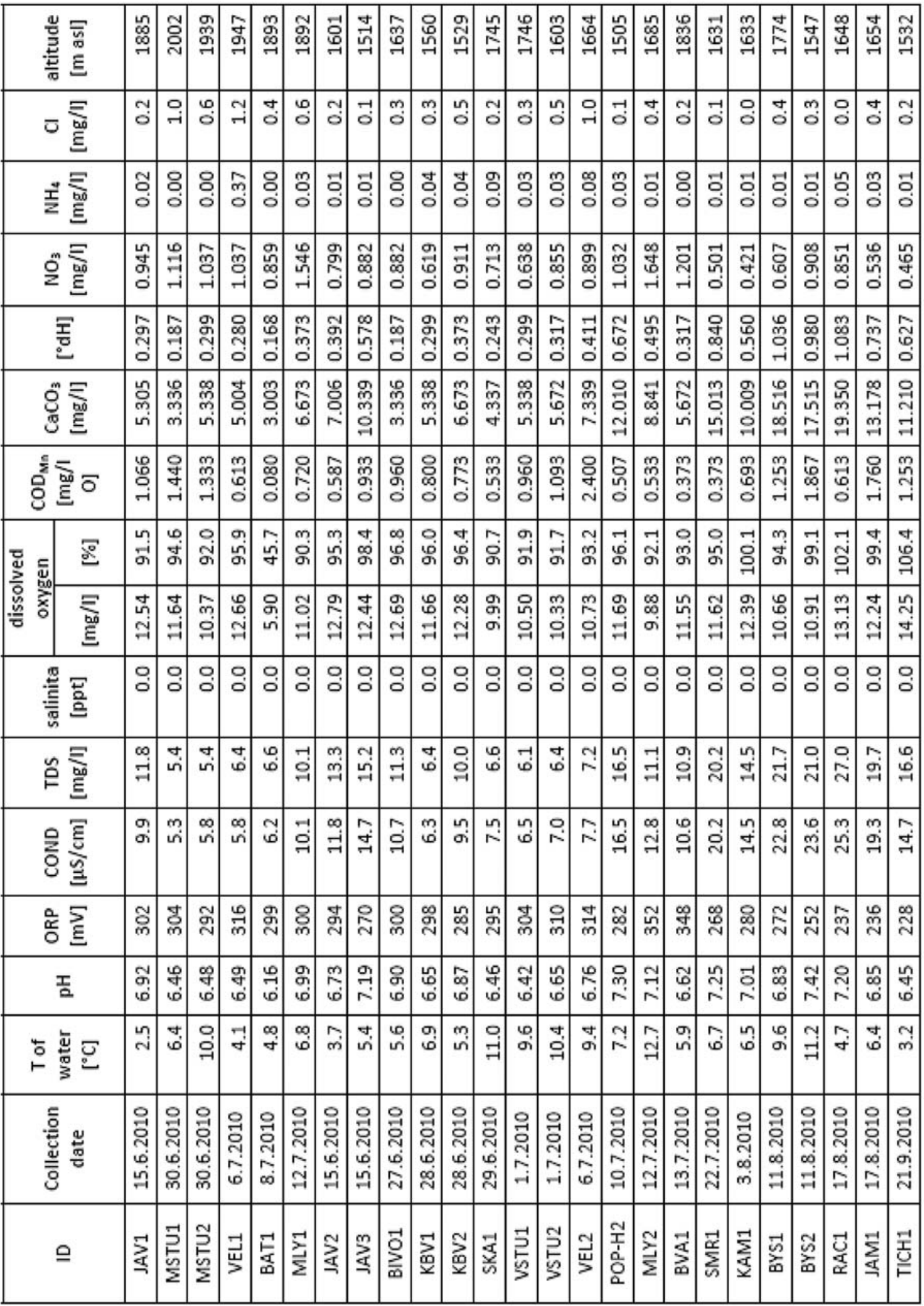




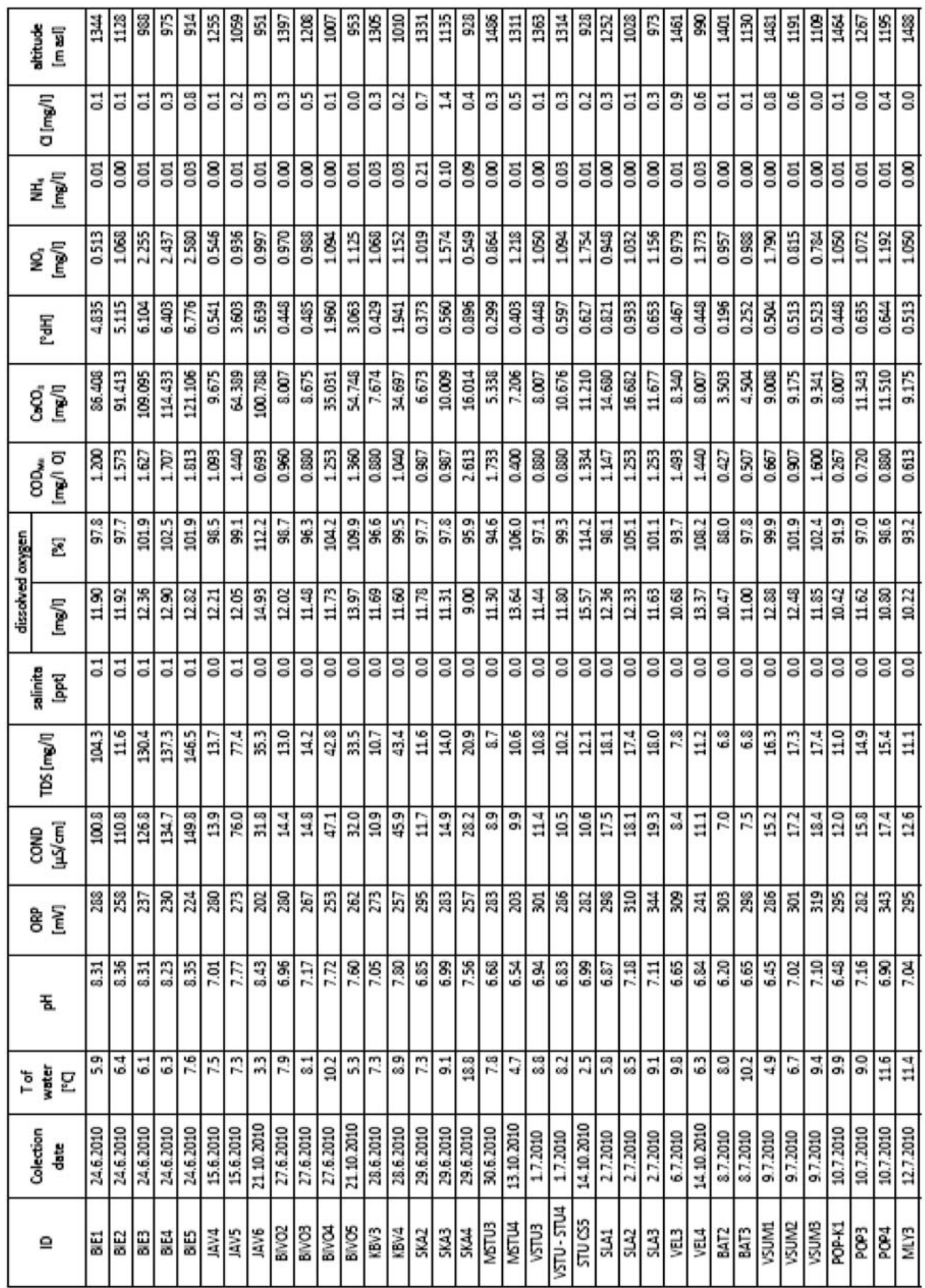




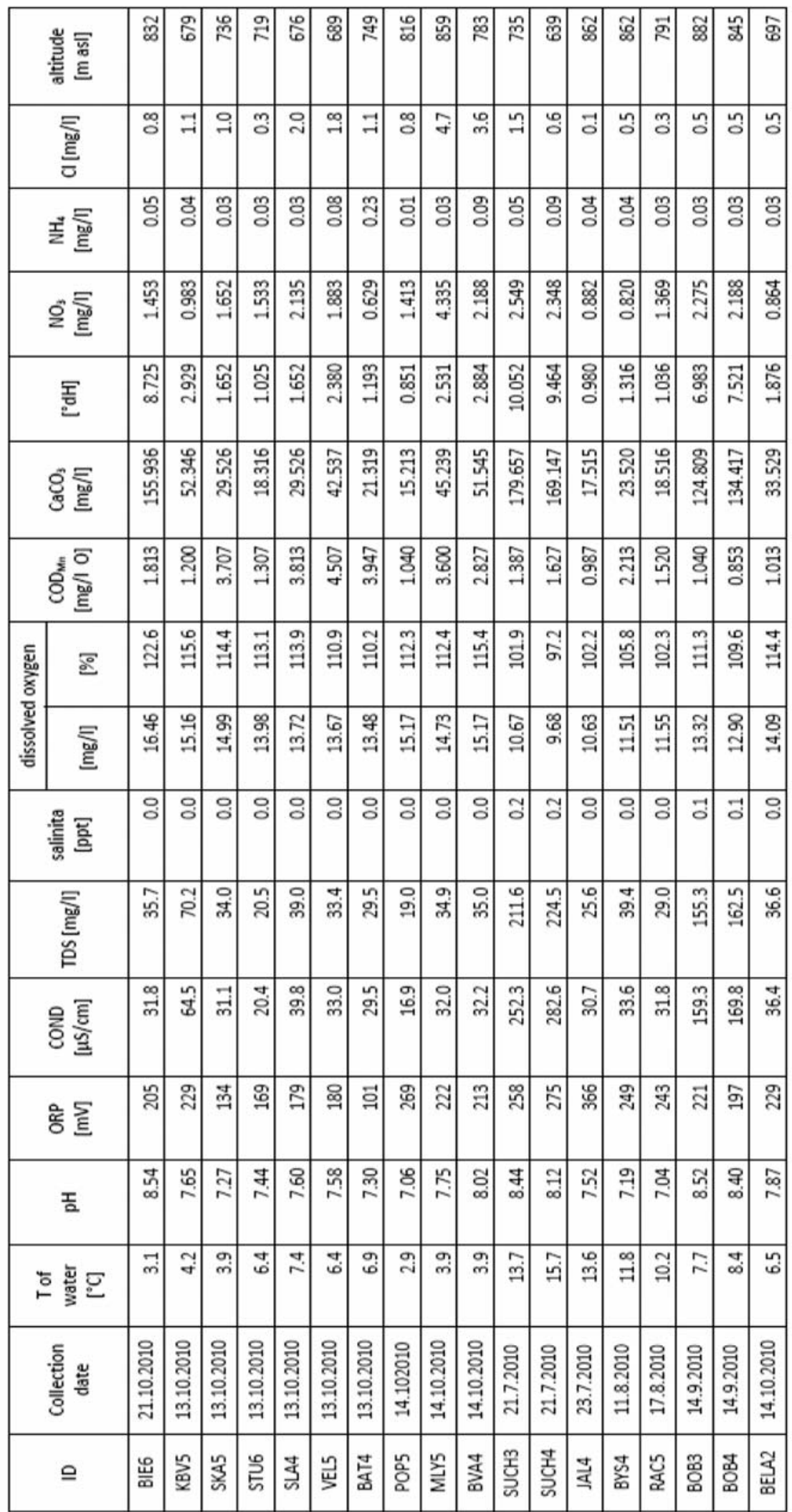


(1648 $\mathrm{m})$ and Bobrovecky potok (1178 m). A slight negative correlation was observed between chlorides and altitude (Fig. 5). The observed values for each parameter in all water courses for which measurements were obtained are shown in Tables 1-3.

\section{Discussion}

Dissolved oxygen is the limiting factor for life of various aquatic organisms. It affects the majority of biochemical processes and is

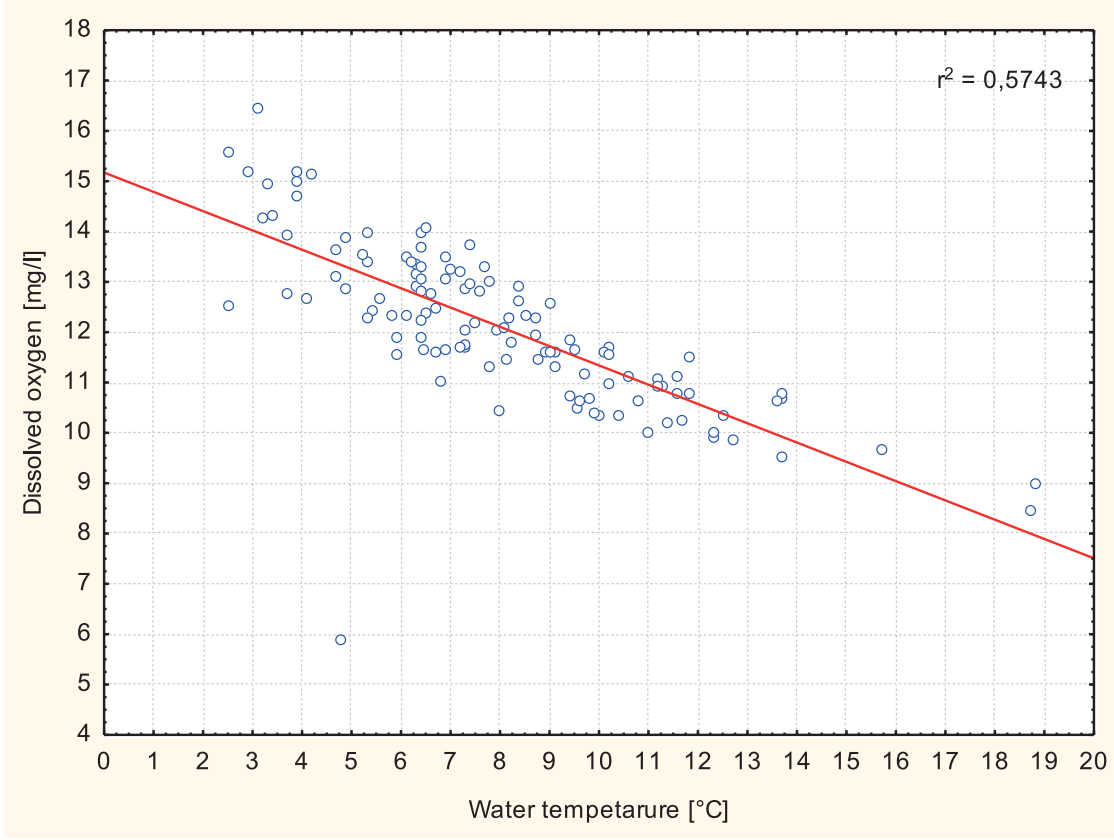

Fig. 2 Relationship between temperature and dissolved oxygen

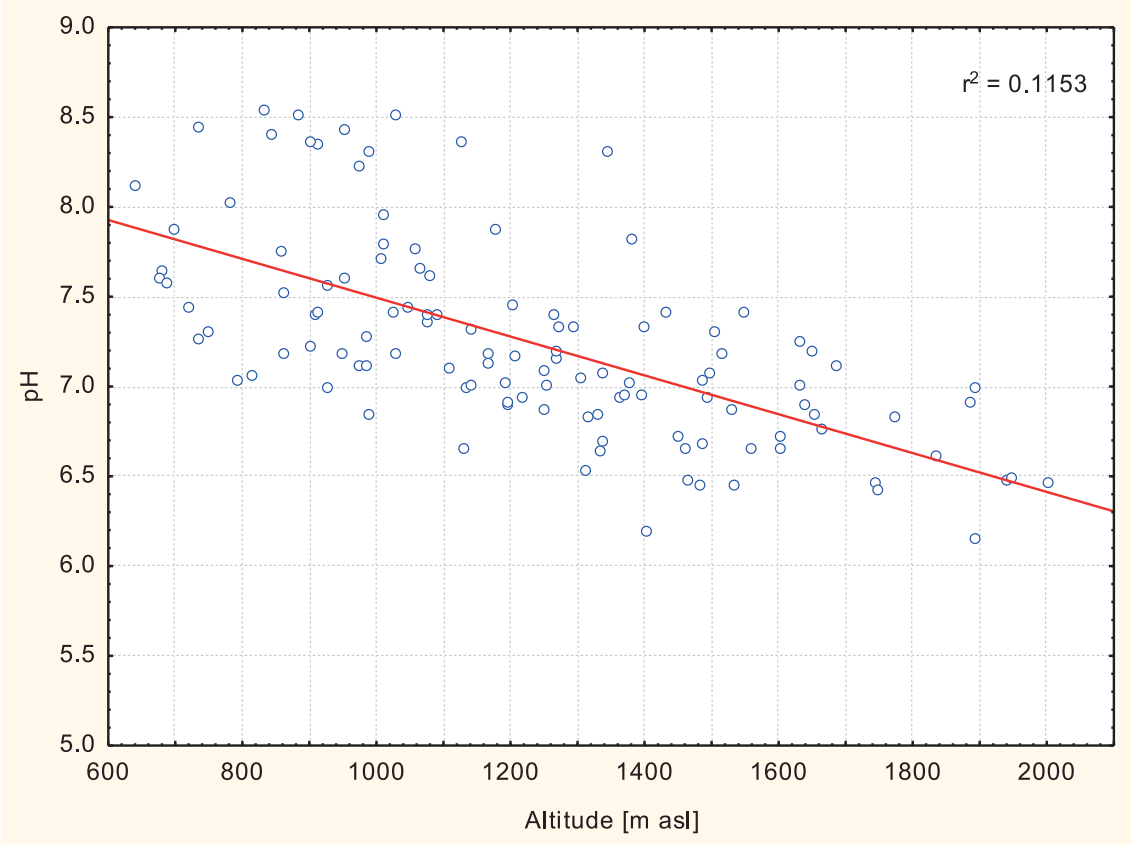

Fig. 3 Relationship between $\mathrm{pH}$ and altitude 


\section{COMMNICOIIONS}

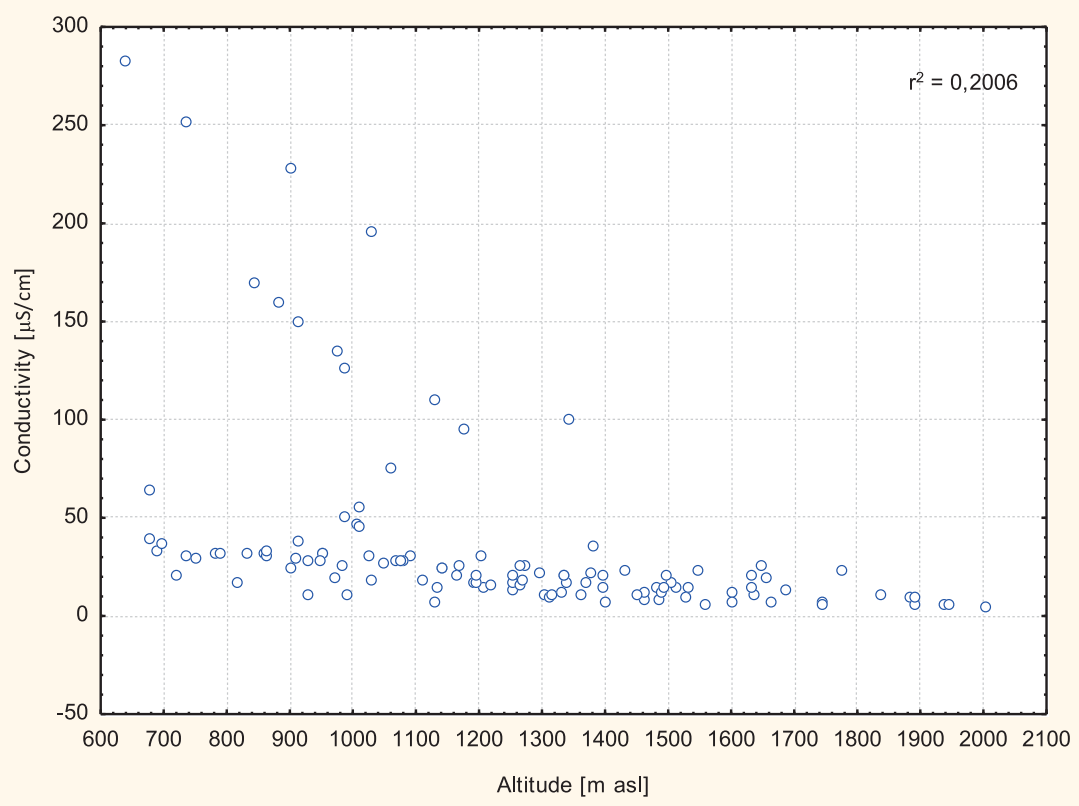

Fig. 4 Relationship between conductivity and altitude

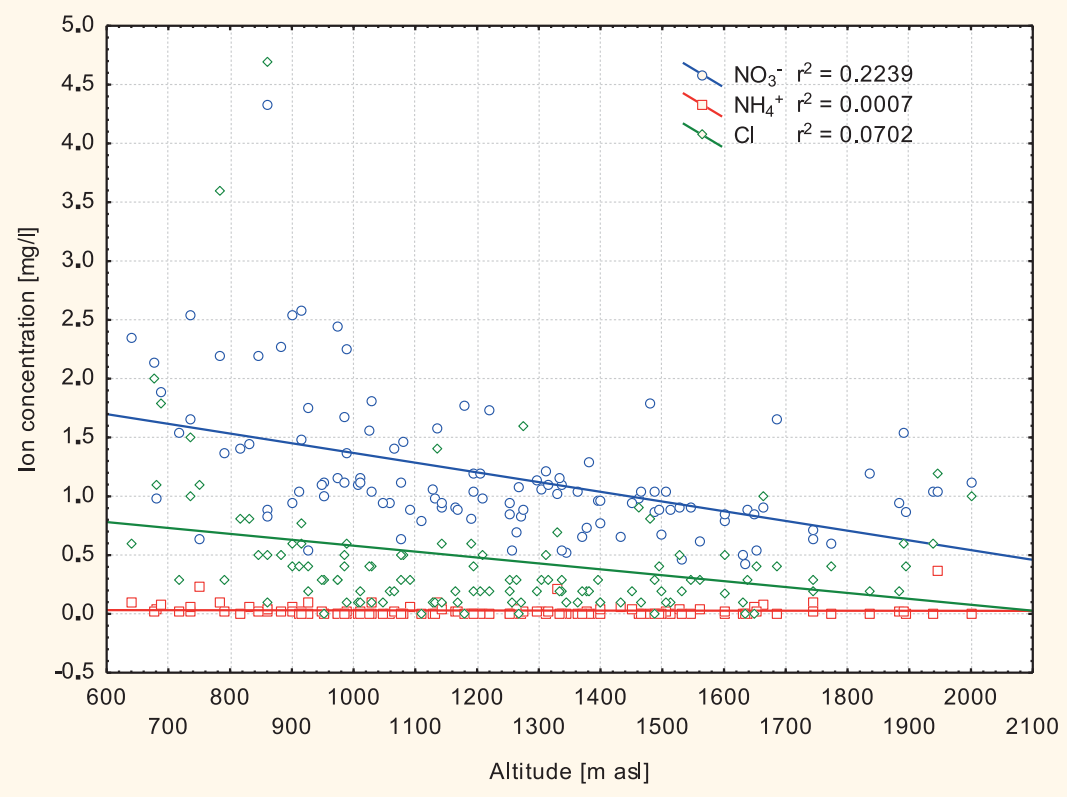

Fig. 5 Relationship between ion concentration $\left(\mathrm{Cl}, \mathrm{NH}_{4}{ }^{+}, \mathrm{NO}_{3}{ }^{-}\right)$and altitude

an important indicator of purity. In flowing water, oxygen of atmospheric origin prevails [23]. Under normal conditions the amount of oxygen varies between 7 and $14 \mathrm{mg} / 1$ [24]. Our study found concentrations from 5.90 to $16.46 \mathrm{mg} / \mathrm{l}$.

Dissolved oxygen decreases with increasing water temperature [25]. However, although water temperature decreases with increas- ing elevation, only a weak relationship $\left(r^{2}=0.1637\right)$ was observed between DO and elevation (Tab. 1-3). The concentration of DO tended to increase up to a certain elevation, but beyond this limit it showed a negative correlation. The relationship between DO and elevation can probably be explained by the diminishing amount of oxygen produced by photosynthesis. The concentration of DO in the water is dependent on atmospheric pressure, sunshine, subse- 
quent algal photosynthetic activity and respiration of all organisms [23]. As our results confirm, DO is affected to a large extent by water temperature (Fig. 2). The majority of these factors are limited at higher elevations.

The $\mathrm{pH}$ of stream water affects the solubility of a spectrum of components and consequently their availability to aquatic organisms [26, 2]. Krno [24] observed that $\mathrm{pH}$ in natural flowing water reaches values of $6.3-8.5$, which is very similar to those observed in our study. Other authors [27] observed an average $\mathrm{pH}$ value of 7.67 in Tatra water courses. $\mathrm{pH}$ is affected by the geological environment, acid rain [25], geochemical reactivity of rocks and the length of time that water is in contact with rock [2]. The highest $\mathrm{pH}$ was recorded on a bedrock of sandstone and conglomerates (BIE6). The lowest $\mathrm{pH}$ was measured on granodiorite bedrock (BAT1) Comparing the $\mathrm{pH}$ between altitudinal vegetation stages, water was more acidic in coniferous forests (1250 - $1550 \mathrm{~m}$ a.s.1.) than in deciduous and mixed forests $(200-1300 \mathrm{~m})$. Spruce stands, in particular, caused higher acidity of the environment [28]. The lowest $\mathrm{pH}$ was observed in the highest streams. It is generally known that $\mathrm{pH}$ decreases with increasing elevation [2].

Conductivity provides information about the concentration of dissolved compounds, particularly inorganic compounds (salts of ammonium, calcium, potassium, sodium, sulphate, chloride, phosphate) [23]. Higher COND indicates higher ion content of dissolved solids in water. COND very significantly depends on water temperature and on the level of anthropogenic load. The occurrence of pollutants in a water course increases the degree of presence of cations and anions in the water. High COND values are a symptom of the presence of anthropogenic load [25]. COND in Tatra water courses ranged from 5.30 to $282.60 \mu \mathrm{S} / \mathrm{cm}$, with an average of $36.30 \mu \mathrm{S} / \mathrm{cm}$.

Total hardness is caused by divalent and polyvalent cations dissolved in water, among which calcium and magnesium ions predominate. Calcium concentration in surface waters corresponds closely to bedrock type [29]. The water courses included in our study were generally very soft, which is probably mainly due to the soil structure (crystalline basement of the Tatras). The highest concentrations of $\mathrm{Na}, \mathrm{Mg}$ and $\mathrm{Ca}$ ions and thus the highest hardness were measured on limestone-granite bedrock. Changes in forestry negatively affect aquatic ecosystems. These changes reduce the concentrations of basic cations, which can affect the hardness of water. Naturally soft water contains less than $50.00 \mathrm{mg} / \mathrm{l}$ of total dissolved solids, is low alkaline and a $\mathrm{pH}$ is in the acidic range [30]. In addition to the bedrock type and anthropogenic activities including not only tourism but also deforestation and urbanization, $\mathrm{Ca}$ and $\mathrm{Mg}$ ions can reach the water by wastewater pollution or from the atmosphere.

Chemical oxygen demand (COD) is used to estimate organic pollution. This may be of natural origin (extracts from leaching of organically rich soils, decomposition of animal and plant bodies) or of artificial origin, which may indicate leakage of toxic chemicals such as pesticides and fertilizers. COD concentration in most streams did not exceed $3.00 \mathrm{mg} / \mathrm{l}$, which is the limit for drinking water [31]. Higher concentrations were measured in water courses flowing through areas with anthropogenic activity.

Ammonia nitrogen $\left(\mathrm{N}^{-\mathrm{NH}_{4}}{ }^{+}\right)$is present in all surface water, both in water polluted by anthropogenic activity as well as in streams with only background levels, where its source is atmospheric deposition [32]. Ammonium ions $\left(\mathrm{NH}_{4}{ }^{+}\right)$in excess of the limit values can indicate faecal contamination, but may be of geological background. Combined with the increasing content of nitrite and higher levels of organic matter (CHSKMn), it signals contamination by fresh animal waste [31]. The amount of ammonia is influenced by many factors, but is most affected by temperature. Several studies indicate that the concentration of ammonia decreases in winter (November, December) and is highest in summer (July and August) [33, 34, 35]. The release of ammonia can also be associated with organic matter mineralization [36], or assimilated by plants and organisms to produce nitrate [37]. Values of ammonia may affect the concentration of $\mathrm{pH}$, thus $\mathrm{pH}$ is higher as the concentration of ammonia increases [34]. In surface water, the concentration of $\mathrm{NH}_{4}{ }^{+}$normally ranges up to $1.00 \mathrm{mg} / 1$ [38, 39]. We observed a concentration of $\mathrm{NH}_{4}{ }^{+}$in selected Tatra water courses of between 0.00 and $0.37 \mathrm{mg} / \mathrm{l}$.

Nitrates $\left(\mathrm{NO}_{3}{ }^{-}\right)$, similar to ammonium ions, are present at low levels in almost all surface water. Greater concentrations are subject to anthropogenic impacts [39]. Nitrate, as well as other anions, decline with increasing altitude $[40,37]$ because they are more diluted due to more precipitation and increasing rainfall and runoff. This observation is consistent with our measurements, where decreasing altitude raised nitrate concentration, which was highest in bedrock of limestone and conglomerates. The main source of nitrate is atmospheric deposition or decomposition of organic matter in soils $[2,41]$. Ground water, which is passed along to surface waters, can also be a source of nitrates [36]. Nitrates are a major source of nutrients for vegetation [39]. Nitrogen is an important biogenic element and is one of the limiting nutrients. However, beside adverse physiological effects, its excess also leads to quite substantial acidification of the environment. In natural waters, nitrate concentrations vary depending on the growing season [24].

Chloride concentrations in surface water in mountainous conditions are dependent only on their concentration in precipitation, in which most of the chloride is formed by marine aerosol formed mainly by sodium chloride. Altitude is another determining factor, because rainfall and run-off increase with higher total precipitation and decreasing temperature, so that the concentration of chloride in surface water is close to the concentration of precipitation (bedrock is not the source) [2]. We did not observe this trend in the streams of TANAP, where no relationship was observed between chloride concentration and altitude.

\section{Conclusion}

The aim of this study was to test the quality of surface water in a representative sample of 28 water courses in Tatra National 
Park. On the basis of one-shot monitoring, during which we measured water temperature, $\mathrm{pH}$, conductivity, salinity, concentrations of total dissolved solids, dissolved oxygen, $\mathrm{Cl}^{-}, \mathrm{NH}_{4}{ }^{+}, \mathrm{NO}_{3}{ }^{-}$, CHSKMn and total hardness, we obtained informative data on water quality. The results obtained were consistent with the rating for very pure water. Results from these sites will form the basis for further monitoring of water quality in the Tatra Mountains.

\section{References}

[1] RUZICKOVA, J., OCASKOVA, I., BENESOVA, L., HLASENSKY, I.: Prirozene a antropogenni faktory ovlivnujici kvalitu vody a diverzitu spolecenstva vodniho hmyzu v tocich na uzemi NP a BR Sumava / Natural and Anthropogenic Factors Affecting the Quality of Water and Diversity of Aquatic Insect Communities in Streams and the National Park Sumava BR (in Czech). Aktuality sumavskeho vyzkumu, 2001, pp. 70-74.

[2] HRUSKA, J., MAJER, V., FOTTOVA, D.: The Influence of Acid Rain on Surface Waters in the Giant Mountains. Opera Corcontica, vol. 43, 2006, pp. 95-110.

[3] KELLER, H. M.: Factors Affecting Eater Quality of Small Mountain Catchments. J. of Hydrology, vol. 9, 1970, pp. 133-141.

[4] DREVER, J. I.: The Geochemistry of Natural Waters. Englewood Cliffs, New Jersey: Prentice Hall, 1982, 388 p.

[5] HOLKO, L., KOSTKA, Z.: Hydrologicky vyskum vo vysokohorskom povodi Jaloveckeho potoka / Hydrological Research of Jalovecky Stream in Mountain River Basin (in Slovak). J. of Hydrology and Hydromechanics, vol. 54, 2006, pp. 192-206.

[6] BENISTON, M.: Climatic Change in Mountain Regions: A Review of Possible Impacts. Climatic Change, vol. 59, 2003 , pp. 5-31.

[7] BENISTON, M., REBETZ, M.: Regional Behavior of Minimum Temperatures in Switzerland for the Period 1979-1993. Theoretical and Applied Climatology, vol. 53, 1996, pp. 231-243.

[8] GOTTFRIED, M., PAULI, H., REITER, K. et al.: A Fine-scaled Predictive Model for Changes in Species Distribution Patterns of High Mountain Plants Induced by Climate Warming. Diversity and Distributions, vol. 5, 1999, pp. 241-251.

[9] MENZEL, A., FABIAN, P.: Growing Season Extended in Europe. Nature, vol. 397, 1999, pp. 659.

[10] PARMESAN, C., YOHE, G.: A Globally Coherent Fingerprint of Climate Change Impacts Across Natural Systems. Nature, vol. 421, 2003, pp. 37-42.

[11] PROCHAZKA, J., HAKROVA, P., POKORNY, J.: Vliv ruzneho zpusobu hospodareni na vyvoj vegetace, toky energie, vody a latek v krajine na prikladu malych povodi / Effect of Different Management on Development of Vegetation, Fluxes of Energy, Water and Matter in Landscape Using Case Studies of Three Small Catchments (in Czech). Aktuality sumavskeho vyzkumu, 2001, pp. 31-34.

[12] MOLDAN, B., SCHNOOR, J.: Czechoslovakia: Examining a Critically Ill Environment. Environmental Science \& Technology, vol. 26, 1992, pp. 14-21.

[13] PACL, J.: Vodstvo / Waters (in Czech). In: Koutna, A. Chovancova, B. (ed.): Tatry - priroda - 1. vyd., Baset : Praha, 2010, pp. 231-234.

[14] BIELY, A., BEZAK, V., ELECKO, M., GROSS, P., KALICIAK, M., KONECNY, V., LEXA, J., MELLO, J., NEMCOK, J., POLAK, M., POTFAJ, M., RAKUS, M., VASS, D., VOZAR, J., VOZAROVA, A.: Geological structure (in Slovak). In: Hrnciarova, T. (ed.): Landscape Atlas of the Slovak Republic $-1^{\text {st }}$ ed. Banska Bystrica: Ministry of Environment of the Slovak Republic Bratislava, Slovak Environmental Agency, 2002, pp. 344. ISBN 80-88833-27-2.

[15] NEMCOK, J., BEZAK, V., JANAK, M. et al.: Explanation of the Geological Map of the Tatra Mountains (in Slovak). State Geological Institute of Dionyz Stur, Bratislava, 1993, p. 135.

[16] BULANKOVA, E., ZATOVICOVA, Z.: Preimaginal Stages of Diptera (excluding Chironomidae and Simuliidae) of Mountain Lakes, their Inlets and Outlets in the Tatra Mountains (Slovakia). Biologia, vol. 61, 2006, pp. 185-190.

[17] KOPACEK, J., KANA, J., SANTRUCKOVA, H. et al.: Chemical and Biochemical Characteristics of Alpine Soils in the Tatra Mountains and their Correlation with Lakewater Quality (in Czech). Water, Air and Soil Pollution, vol. 153, 2004, pp. 307-327.

[18] TOMLAIN, J.: Mean Annual Values of Climatic Moisture Index (in Slovak). In: Hrnciarova, T. (ed.): Landscape Atlas of the Slovak Republic $-1^{\text {st }}$ ed., Banska Bystrica: Ministry of Environment of the Slovak Republic Bratislava, Slovak Environmental Agency, 2002, p. 344, ISBN 80-88833-27-2.

[19] PACL, J.: Navrh na statne prirodne rezervacie v tatranskom narodnom parku z hydrologickeho hladiska / Hydrological terms of The National Nature Reservation Proposal in the Tatra National Park (in Slovak), Zbornik prac o Tatranskom narodnom parku, vol. 29, 1989.

[20] PISUT, P., TOMCIKOVA, I.: Rekonstrukcia vyvoja rieky Smrecianky v jej odozvovej zone podla historickych map / Reconstructed Evolution of Lower Smrecianka River in its Response Zone According to Historical Maps. Geographia Cassoviensis II., vol. 1, 2008, pp. 122-127.

[21] ISO 5667-3: 2003 Water quality - Sampling - part 3: Guidance on the preservation and handling of samples (75 7051$)$ - (in Slovak). 
[22] HORAKOVA, M., LISCHKE, P., GRUNWALD, A.: Chemicke a fyzikalni metody analyzy vod / Chemical and Physical Methods of Water Analysis - 2. ed. (in Czech), Praha: SNTL - nakladatelstvi technicke literatury, 1989, p. 389.

[23] HVIZDAL, J., ZACHAROVA, J.: System provozu monitoringu Zemedelske vodohospodarske spravy (ZVHS) - metodicke zasady / Operation Monitoring System of Agricultural Water Management (in Czech). ZVHS Odbor spravy informaci, Brno.

[24] KRNO, I.: Limnologia tecucich vod / Limnology of Flowing Waters (in Slovak). Bratislava : Univerzita Komenskeho, 2009, p. 73, ISBN: 9788022325301.

[25] LANGHAMMER, J.: Analysis of the Relationship between Stream Regulations and the Geomorphologic Effects of Floods (in Czech). Natural Hazards, vol. 54, 2010, pp. 121-139.

[26] WOHL, E.: Mountain Rivers. Water Resources Monograph Series, vol. 14, AGU, Washington, D. C., 2000, p. 320. ISBN: 0-87590318-5.

[27] ZELAZNY, M., ASTEL, A., WOLANIN, A., MALEK, S.: Spatiotemporal Dynamics of Spring and Stream Water Chemistry in a High-mountain Area. Environmental Pollution, vol. 159, 2011, pp. 1048-1057.

[28] HRUSKA, J., CIENCALA, E.: Long-term Acidification and Nutrient Degradation of Forest Soils - Limiting Factors of Forestry Today. In: Hruska, J., Ciencala, E. (ed.): Long-term Acidification and Nutrient Degradation of Forest Soils - Limiting Factors of Forestry Today. Praha, 2003, p. 165, ISBN 80-7212-190-1.

[29] LANGHAMMER, J., HARVICH, F., MATTAS, D., RODLOVA, S., ZBORIL, A.: The Variability of Surface Water Quality Indicators in Relation to Watercourse Typology, Czech Republic. Environmental Monitoring and Assessment, vol. 184, pp. 3983-3999.

[30] HARRISON, J. F.: Why Naturally Soft and Softened Water are not the Same. Intern. Symposium on Health Aspects of Calcium and Magnesium in drinking Water (NSF/ILSI/WHO) in Baltimore, 2006.

[31] Ukazovatele kvality pitnej vody - Charakteristika vybranych ukazovatelov kvality pitnej vody / Characteristics of Selected Indicators of Drinking Water Quality (in Slovak). Online: http://pitnavoda.enviroportal.sk/ukazovatele-kvality-pitnej-vody. 20. 04. 2011.

[32] PITTER, P.: Hydrochemie / Hydrochemistry (in Czech). Vydavatelstvo VSCHT, Praha, 1999, p. 568. ISBN 80-7080-340-1.

[33] KRNO, I., SPORKA, F., GALAS, J., et al.: Littoral Benthic Macroinvertebrates of Mountain Lakes in the Tatra Mountains (Slovakia, Poland). Biologia, vol. 61, 2006, Supp., pp S147-S166.

[34] ADAM, S., PAWERT, M., LEHMANN, R. et al.: Physicochemical and Morphological Characterization of Two Small Polluted Streams in Southwest Germany. J. of Aquatic Ecosystem Stress and Recovery, vol. 3, 2001, pp. 179-194.

[35] ZASEPA, P., RADECKI-PAWLIK, A., KLONOWSKA-OLEJNIK, M., PRZYBYLA, K.: Differential Types of Community Structures of Benthic Macro-invertebrates within the Region of the Mountainous Stream Point Bar. Polska Akademia Nauk, Oddział w Krakowie, Nr. 2, 2006, pp. 5-16.

[36] BUTTURINI, A., SABATER, F.: Nitrogen Concentrations in a Small Mediterranean Stream: 1. Nitrate 2. Ammonium. Hydrology and Earth System Sciences, vol. 6, 2002, pp. 539-550.

[37] KOPACEK, J., HEJZLAR, J., MOSELLO, R.: Estimation of Organic Acid Anion Concentrations and Evaluation of Charge Balance in Atmospherically Acidified Colored Waters. Original Research Article Water Research, vol. 34, 2000, pp. 3598-3606.

[38] NARIADENIE VLADY SR c. 296/2005 Z. z., ktorym sa ustanovuju poziadavky na kvalitu a kvalitativne ciele povrchovych vod a limitne hodnoty ukazovatelov znecistenia odpadovych vod a osobitnych vod / Establishing the Quality and Surface Water Quality Objectives and Limit Values Indicators of Waste Water and Special Water (in Slovak), 2005, pp. 2928-2991.

[39] LANGHAMMER, J.: Kvalita povrchovych vod a jejich ochrana / Quality of Surface Waters and Their Conservation (in Czech). PrF UK, Praha, 2002, p. 225.

[40] HOOD, E., McKNIGHT, D. M., WILLIAMS, M. W.: Sources and Chemical Character of Dissolved Organic Carbon Across an Alpine/Subalpine Ecotone, Green Lakes Valley, Colorado Front Range, United States. Water Resources Research, vol. 39, 2003, p. 12.

[41] JOHNSON, D. W., FRIEDLAND, A. J., VAN MIEGROET, H., HARRISON, R. B., MILLER, E., LINDBERG, S. E., COLE, D. W., SCHAEFER, D. A., TODD, D. E.: Nutrient Status of Some Contrasting High Elevation Forest in the Eastern and Western United States, Proc. of U.S.-German Research Symposium: Effects of Atmospheric Pollutants on the Spruce-fir Forests of the Eastern United States and the Federal Republic of Germany. Northeastern Forest Experiment Station Gen. Tech. Rep. NE-120, Broomall, PA, 1989, pp. 463-469. 